\title{
Oil and Fatty Acids Composition in Glasswort (Salicornia Fruticosa) Seeds
}

\author{
Elsebaie, E. M.;Elsanat, S. Y.; Gouda, M. S. and Elnemr, K. M. \\ Food technology. Dept., Fac. Agric., Kafr El-Sheikh Univ., Egypt
}

\begin{abstract}
Salicornia fruticosa) is the most widely distributed species of the perennial genus of glasswort in Egypt and it shows great biotechnological potential as a salt-water irrigated crop. Oil analysis of Salicornia fruticosa seeds was carried out in the current study. Chloroform and methanol mixture $(2: 1 v: v)$ extraction yielded maximum oil content from seeds (28.59\%). The physical and chemical characteristics of Salicornia fruticosa seed oil were also analyzed. The results were as follows: the iodine value $84.5 \mathrm{gI} / 100 \mathrm{~g}$ oil, acid value $1.84 \mathrm{mgKOH} / \mathrm{g}$ oil and saponification value $195.6 \mathrm{mgKOH} / \mathrm{g}$ oil. The unsaturated fatty acids accounted for $78.05 \%$, in which oleic acid accounted for $56.58 \%$, linoleic acid accounted for $17.40 \%$, and linolenic acid accounted for $3.98 \%$. It showed that Salicornia fruticosa seed oil was a high quality health oil.
\end{abstract}

Key Words: glasswort, fatty acids composition, oleic acid, oilseeds, Salicornia fruticosa.

\section{Introduction}

Glassworts or marsh samphires are small succulent shrubs native to coastal marshes, mangroves and salt deserts, as well as a potential new seed oil crop for direct irrigation with salt water [1;2 and 3]. Glassworts are members of three closely related genera (Salicornia, Sarcocornia and Arcthronemum) of the subfamily Salicornioideae (family Chenopodiaceae) [4;5 and 6]. The most successfully cultivated glasswort is the annual Salicornia bigelovii. Seeds of S. bigelovii may contain 26-33\% of fatty acids [7; 1 and 8], exceeding levels of traditional oil-seeds such as cotton (15-24\%) and soybean (17-21\%) [7 and 8]. The average annual seed production of this species (Salicornia bigelovii) varies from 2.0 [1] to 3.7 tonnes/hectare/year [9].

The cultivation of S. bigelovii has been successful in the U.S., Mexico, Saudi Arabia, the United Arabic Emirates, Egypt, Eritrea and Pakistan [9; 7, 8 and 3]. Several researchers have emphasized the importance of halophyte oil as a potential source of polyunsaturated fat and biodiesel supply for growing global demands [1 and 10]. The predominant fatty acid in glasswort (salicornia fruticosa) seed oil was linoleic acid and no fatty acids exceeding 20 carbons detected. Saturated fatty acids accounted for $19.98 \%$ of the fat. The polyunsaturated fatty acids accounted for $19.98 \%$ of the fat [11]. glasswort (salicornia fruticosa) seed oil was found to contain high levels of linoleic acid (74.66-79.49\%) and less oleic acid (12.33-16.83\%). Saturated fatty acids, palmitic acid ranged from 7 to $8.50 \%$ and stearic acids ranged from 1.24 to $1.69 \%$. Linolenic acid (C(18:3) omega-3) was found within the range of 1.50 to $2.31 \%$ [8]. The study was undertaken to analyse content, fatty acid composition and physico-chemical parameters of glasswort seeds oil as a new resource for oil.

\section{Plant material}

\section{Materials and Methods}

Glasswort (salicornia fruticosa) was collected from international coastal road near El-Boruls city, Kafr ElSheikh Governorate, Egypt (latitude $32^{\circ} 35^{\circ} \mathrm{N}$ and longitude31 $1^{\circ} 16^{\circ}$ E) during January 2012. All chemicals and solvents used in this investigation (HPLCspectral grade) were purchased from El-Gomhorea company, Egypt. Seeds were obtained by milling the dry plants in a hammer mill and the chaff was screened on a series of agricultural screens. Air from a blower was used to separate chaff and seed material[1].

\section{Methods}

\section{Gross chemical composition}

Moisture, crude protein, ether extract, ash and crude fiber content were determined [12]. Total carbohydrates were calculated by difference.

\section{Oil extraction}

The total oil from the seeds was extracted following the solvent method using hexan, petroleum ether and cholorform: methnol mixture $(2: 1 \mathrm{v} / \mathrm{v})$. about $100 \mathrm{~g}$ powdered seed immersed in solvent was agitated in a conical flask for $24 \mathrm{~h}$. the residue was allowed to settle and supernatant was decanted and heated to $400^{\circ} \mathrm{C}$ until solvent was completely evaporated. The final weight of solid material left after evaporation was noted. 


\section{Physico-chemical properties}

For physico-chemical properties of oil specific density were determined at room temperature $\left(28^{\circ} \mathrm{C}\right)$ using a specific density bottle. Iodine, acid, saponification, peroxide and ester values were determined [12].

\section{Fatty acid profiles}

Fatty acids compostion of glasswort (Salicornia fruticosa) seeds oil was determined using gas chromatography (GC Model, Shimadzu-8A, equipped with a FID detector and glass column $2.5 \mathrm{~m} \times 3 \mathrm{~mm}$ id, under the following: Column 5\% Degs on 80/100 Chromo Q, Detector temperature $270{ }^{\circ} \mathrm{C}, \mathrm{H} 2 \mathrm{Flow}$ rate $75 \mathrm{~mL} /$ min, sensitivity $16 \times 102$, Column temperature $150-180^{\circ} \mathrm{C}$ at rate $2^{\circ} \mathrm{C} / \mathrm{min}, \mathrm{N} 2$ flow rate $20 \mathrm{~mL} / \mathrm{min}$, air flow rate $0.5 \mathrm{ml} / \mathrm{min}$ and start speed $2.5 \mathrm{~mm} / \mathrm{min}$ )[13].

\section{Results and Discussion}

Table (1) shows gross chemical composition of glasswort (salicornia fruticosa) seeds. Data indicate that, moisture, crude protein, ether extract, ash, crude fiber and total carbohydrate contents of glasswort (salicornia fruticosa) seeds were 6.89, 28.2, 27.48, 6.96, 6.39 and 30.97, respectively these results are in agreement with those reported in another study [14 and 15].

Table 1: Gross chemical composition of glasswort (salicornia fruticosa) seeds (\% on dry weight bases)

\begin{tabular}{|l|c|}
\hline Components & $\%$ \\
\hline \hline Moisture & 6.89 \\
\hline \hline Crude protein & 28.20 \\
\hline \hline Ether extract & 25.48 \\
\hline \hline Ash & 6.96 \\
\hline \hline Crude fiber & 8.39 \\
\hline \hline Total carbohydrate & 30.97 \\
\hline \hline
\end{tabular}

Seed oil extracted from glasswort (salicornia fruticosa) varied in yields using three solvent systems, viz. hexan, petroleum ether and chloroform: methnol mixture $(2: 1 \mathrm{v} / \mathrm{v})$. maximum oil yield of $28.59 \%$ was obtained when the seeds was extracted with chloroform: methnol mixture $(100 \mathrm{ml} / 100 \mathrm{~g}$ seed) for $24 \mathrm{~h}$ (Table 2). Whereas $100 \mathrm{ml}$ of hexan was required for $100 \mathrm{~g}$ seed to get $24.61 \%$ oil yield (Table 2). Thus, chloroform: methnol mixture $(2: 1 \mathrm{v} / \mathrm{v})$ extraction gave higher oil yield compared to extraction with hexan or petroleum ether.

Table 2 : Total oil extraction using hexan, petroleum ether and cholorform: methnol mixture (2:1 v/v).

\begin{tabular}{|l|c|}
\hline \hline Solvent type & Oil extraction \\
\hline \hline Hexan & 24.61 \\
\hline \hline Petroleum ether & 25.98 \\
\hline \hline Cholorform: methnol mixture $(2: 1 \mathrm{v} / \mathrm{v})$ & 28.59 \\
\hline
\end{tabular}

Table (3) presents physico-chemical properties of glasswort (salicornia fruticosa) seeds oil. Acomparison of seed oil properties with olive oil also Table (3) revealed that iodine and peroxide values were lower than olive oil on the other hand, acid and saponfication values of salicornia seeds oil were higher than olive oil. Its saponification and iodine values are quite close to that of semi dry oils such as corn, cotton seed and sunflower oils. The above result are in accordance with those reported in another study [8; 16 and 17]. 
Table 3: Physico-chemical properties from salicornia fruticosa seeds oil

\begin{tabular}{||l||l||l||}
\hline \hline properties & salicornia fruticosa seeds oil & Olive oil [18] \\
\hline \hline Specific gravity $\left(28^{\circ} \mathrm{C}\right)$ & 0.918 & - \\
\hline \hline Iodine value $(\mathrm{gI} / 100 \mathrm{~g})$ & 84.5 & 89.00 \\
\hline \hline Acid value $(\mathrm{mg} / \mathrm{g})$ & 1.84 & 0.20 \\
\hline \hline Saponification value $(\mathrm{mg} / \mathrm{g})$ & 195.6 & 186.00 \\
\hline \hline Peroxide value $\left(\mathrm{mEqO}_{2} / \mathrm{kg}\right.$ oil) & 1.3 & 2.50 \\
\hline \hline
\end{tabular}

The GC analysis of glasswort (salicornia fruticosa) seeds oil showed nine fatty acids prominent. The oil was composed of 17.40 wt.\% linoleic- $\omega 6$ acid (18:2), 16.40 wt.\% palmitic acid (16:0), 56.58 wt.\% oleic acid (18:1), 2.5 wt.\% stearic acid (18:0) and 3.98 wt.\% linolenic- $\omega 3$ acid (18:3) as shown in Table (4).

Table 4: Fatty acids profile of from salicornia fruticosa seeds oil.

\begin{tabular}{|l|c|c|}
\hline \multicolumn{1}{|c|}{ Acid } & Symbol & $\%$ \\
\hline \hline Luric & $\mathrm{C}_{12: 0}$ & 0.91 \\
\hline \hline Myristic & $\mathrm{C}_{14.0}$ & 1.78 \\
\hline \hline Palmitic & $\mathrm{C}_{16.0}$ & 16.40 \\
\hline \hline Palmitolic & $\mathrm{C}_{16: 1}$ & 0.09 \\
\hline \hline Stearic & $\mathrm{C}_{18: 0}$ & 2.50 \\
\hline \hline Oleic & $\mathrm{C}_{18: 1}$ & 56.58 \\
\hline \hline Linolic & $\mathrm{C}_{18: 2}$ & 17.40 \\
\hline \hline Linolenic & $\mathrm{C}_{18: 3}$ & 3.98 \\
\hline \hline Arachidic & $\mathrm{C}_{20.0}$ & 0.36 \\
\hline \hline Total Saturated & $\%$ & 21.95 \\
\hline \hline Total Unsaturated & $\%$ & 78.05 \\
\hline \hline U / S ratio* & & $3.56: 1$ \\
\hline \hline
\end{tabular}

*Unsaturated/Saturated ratio

The oil was rich in polyunsaturated fatty acids, particularly oleic and linoleic acid, which has medical significance and, more specifically, the oil contained a small amount of C18:3 linolenic- $\omega 3$, which may result in better oil stability than commercial oils [7]. For instance, soyabean oil contains up to $6.8 \%$ of linolenic- $\omega 3$, and it is less stable due to fast oxidation when compared to Salicornia bigelovii seed oil, which has only $1.4 \%$ of this fatty acid [7]. The sum of saturated acids (21.95\%) in glasswort (salicornia fruticosa) seed oil represents a major quantitative difference in comparison to commercial oils. Intermediate values of saturated acids were found in seeds from Salicornia brachiata (16.5\%) [16] and the chenopod Suaeda fruticosa (17.0\%) [14]. Similar high concentrations of palmitic acid (21.8-29.4\%) were found in seeds of salt fat and coastal dune halophytes (Arthrocnemum macrostachyum, Haloxylon stocksii, Alhagi maurorum, Cressa cretica and Halopyrum mucronatum) from Asia [14].

\section{References}

[1]. Glenn, E. P.; O’leary, J. W.; Watson, M. C.; Thomas, T. L and Kuehl, R. O. Salicornia bigelovii Torr.: an oilseed halophyte for seawater irrigation. Science, 251, 1991, 1065-1067.

[2]. Costa, C. S. B. Restoration of coastal habitats in Brazil using native salt marsh plants. In: Greipsson S (Ed), Restoration Ecology, Sudbury (MA. U.S.A.): Jones and Bartlett Publishers, 2011, p. 333-338.

[3]. Zerai, D. B.; Glenn, E. P.; Chatervedi, R, L.; Mamood, A. N.; Nelson, S. G and Ray, D. T. Potential for improvement of Salicornia bigelovii through selective breeding. Ecol Eng 36, 2010, 730-739. 
[4]. Shepherd, K. A.; Macfarlane, T. D and Colmer, T. D. Morphology, anatomy and histochemistry of Salicornioideae (Chenopodiaceae) fruits and seeds. Ann Bot (Lond) 95, 2005, 917-933.

[5]. Davy, A. J.; Bishop, G. F.; Mossman, H.; Redondo-gómez, S.; Castillo, J. M.; Castellanos, E. M.; Luque, T and Figueroa, M. E. Biological Flora of the British Isles, n. 244. Sarcocornia perennis (Miller) A. J. Scott. J Ecol 94, 2006, $1035-1048$.

[6]. Alonso, M. A and Crespo, M. B. Taxonomic and nomenclatural notes on South American taxa of Sarcocornia A. J. Scott (Chenopodiaceae). Ann Bot Fennici 45, 2008, 241-254.

[7]. El-mallah, M. H; Turui, T and El-shami, S. Detailed studies on seed oil of Salicornia SOS-7 cultivated at the egyptian border of Red Sea. Grasas Aceites 45(6), 1994, 385-389.

[8]. Anwar, F.; Bhanger, M. I.; Nasir, M. A and Ismail, S. Analytical characterization of Salicornia bigelovii seed oil cultivated in Pakistan. J Agric Food Chem 50, 2002, 4210-4214.

[9]. Clark, A. Samphire: from sea to shining seed. Saudi Aramco World 45(6), 1994, 2-9.

[10]. Ruana, C. J.; Lia, H; Guob, Y. Q.; Inb, P.; Gallagherc, J. L.; Seliskarc, D. M.; Luttsd, S and Mahye, G. Kosteletzkya virginica, an agroecoengineering halophytic species for alternative agricultural production in China's east coast: Ecological adaptation and benefts, seed yield, oil content, fatty acid and biodiesel properties. Ecol Eng 32(4), 2008, 320-328.

[11]. Attia, F. M.; Alsobayel, A. A; Kriadees, M. S.; Al-Saiady, M. Y. and Bayoumi, M. S. Nutrient composition and feeding value of salicornia bigelovii torr meal in broiler diets. Animal feed science technology 65, 1997, 257-263.

[12]. Association of Official Analytical Chemists. Official methods of analysis.; $17^{\text {Th }}$ ed. Washington, DC., USA, 2000.

[13]. D’oca, M. G. M.; Viêgas, C. V.; Lemões, J. S.; Miyasaki, E. K.; Morón-villarreyes, J. A.; Primel, E. G and Abreu, P. C. Production of FAMEs from several microalgal lipidic extracts and direct transesterifcation of the Chlorella pyrenoidosa. Biomass Bioenergy 35 , 2011, 1533-1538.

[14]. Weber, D. J.; Ansarib, R.; Gulb, B and Ajmal, K. M. Potential of halophytes as source of edible oil. J Arid Environ 68, 2007, 315321.

[15]. Epagri, K. Panicêutivo-Você sabe o que significa? Agropecuária Catarinense 21(2), 2008, 13.

[16]. Eganathan, P.; Subramanian, H. M. S.; Latha, R and Rao, C. S. Oil analysis in seeds of Salicornia brachiata. Ind Crops Prod 23, 2006, 177-179.

[17]. Hongshan, L. I and Yanxia, F.A.N. Extraction and characteristics analysis of Suaeda salsa seed oil. Journal of China Oils and Fats 30, 2010, 1522-1527.

[18]. Arafat, S.M.; Gaafar, A.M.; Basuny, A. M. and Nassef, S. L. (2009). Chufa tubers (Cyperus esculentus): As a new source of food. World Applied Sci. J., 7(2), 2009, 151-156. 